\section{ECONOMICS}

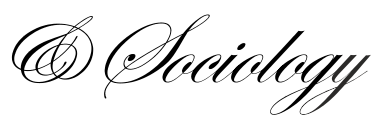

\title{
RETIREMENT PLANNING: COMPARISON BETWEEN POLISH AND SOUTH AFRICAN PROFESSIONAL SOCCER PLAYERS
}

\author{
Manilall Dhurup \\ Vaal University of Technology, \\ South Africa \\ E-mail: royd@vut.ac.za \\ ORCID 0000-0002-8845-3527 \\ Jhalukpreya Surujlal \\ North-West University \\ South Africa \\ E-mail:Babs.Surmilal@,nwu.ac.za \\ ORCID 0000-0003-0604-4971 \\ Sebastian Kot \\ Crestochowa University of \\ Technology, Poland \\ North-West University, \\ South Africa \\ E-mail:sebacat@,zim.pcz.czest.pl \\ ORCID 0000-0002-8272-6918
}

Received: October, 2019

1st Revision: March, 2020

Accepted: June, 2020

DOI: $10.14254 / 2071-$

789X.2020/13-2/7

JEL Classification: L83, Z2
ABSTRACT. Retirement from playing professional sport is an inevitable outcome experienced by professional soccer players due to their limited time span within competitive environments. Preparing for retirement may unexpectedly occur (sometimes without warning, e.g., due to injuries) and may pose challenges for players. This study is an attempt to ascertain whether there are any significant differences in retirement planning between South African and Polish professional soccer players. The study is embedded within a quantitative research paradigm in order to discern such differences. Descriptive statistics were used to report on the demographic profile of the sample and ttests were computed to account for the differences in retirement planning practices between professional soccer players in these two countries. The results of the study reveal that differences do exist in the retirement planning of professional Polish and South African soccer players. Based on the results of the study it is recommended that athletes should be aware of the type of support they will get from their organisations and plan for their retirement accordingly. The respective soccer clubs should also play a greater role in ensuring they support their players adequately and prepare them for a more stable future. Professional soccer players, particularly South African ones, should attend workshops and information sessions on retirement planning so that they can be better prepared for retirement.

Keywords: retirement planning, soccer, professional soccer players, Poland, South Africa

\section{Introduction}

An inevitable reality that all professional athletes have to face is retirement from competitive environments (Fortunato \& Marchant, 1999) and in some instances from sport participation as such (Lavallee, 2005). Unlike traditional retirements which come after long periods of time, accompanied by many years of work experience, retirement from competitive sport occurs at an relatively early age, after a short career span. Riffkin (2014) affirms that professional athletes retire at an average age of 35 years as compared to those in other professions whose average retirement age ranges between 60 to 65 years. Unlike other 
professions where individuals are either in a position to determine and plan when they want to retire or are expected to retire, in professional sports retirement might take place due to unexpected or forced event/s, thus resulting in severe psychological and lifestyle changes. Attuning to such changes pose challenges to professional soccer players who have not yet reached an obligatory retirement age, when compared to other professions (other than sports). Their inability to adjust to changes may result in them experiencing more adjustment challenges while transitioning from a well-paid income group as compared to those professionals who have been belonging to the mainstream society for a long time.

Previous studies (Alfermann, 2000; McKenna \& Thomas, 2007; Hinton, Johnstone, Blaine, \& Bodling, 2011; Locher, 2016) have reported high levels of depression, suicide, cardiovascular disease, eating disorders, substance abuse, and bankruptcy associated with retirement from professional sports. Further, Locher (2016) cites identity crises, health, retirement decision, meaningful postemployment activity, financial status, and available support resources as the determinants which may contribute to a professional athlete's retirement experience outcomes in a negative way.

Soccer is among the most popular sports played worldwide. Playing professional soccer is regarded as a full-time job (Gouttebarge \& Aoki, 2014). Con-commitment with playing professional soccer at the highest level, relevant benefits that accrue for players (e.g., healthcare, pension etc.) are associated with this job. Previous studies (Drawer \& Fuller, 2002; Surujlal \& Maseko, 2012; Gouttebarge \& Aoki, 2014) found that, besides medical support (which is necessary for continuation of their playing career) professional soccer players rarely get other benefits during or after their retirement from playing soccer. In South Africa, Maseko and Surujlal's (2011) study affirms that, unlike the employees in industrial jobs, the devotion shown by professional soccer players by engaging in highly skilled manual labour in their careers is performed willingly because of the self-fulfilment associated with occupation. Furthermore, the authors argue that playing professional soccer is a form of employment that is highly conditional because it requires the retention of a relatively high level of skills and concomitant creativity.

While retirement planning has been well researched and documented, there exists limited research evidence on retirement planning of professional soccer players across the countries. Retirement from professional soccer may occur due to several reasons. Among these are deselection, lack of form, injuries and management decisions, all of which may surface unexpectedly (Surujlal, 2016). Professional soccer players should therefore be prepared for such situations. In some instances retirement from playing professional soccer also occurs out of one's own choice.

\section{Purpose of the study}

This study discerned whether there are differences retirement planning initiatives between South African and Polish professional players.

\section{Methodology}

A literature review which provided a theoretical foundation to identify the problem and decide on the research design was undertaken. Particularly, we investigate the retirement planning basing on the common approaches for pension provision (Mendryk, 2017; Mertl et al., 2019) and considering the consequences of retirees' satisfaction with level of life (D'Silva \& Samah, 2018; Mishchuk \& Grishnova, 2015) within the public policy of social justice and well-being ensuring (Bilan et al., 2020 Mishchuk et al., 2019). The study was imbedded 
within a quantitative research paradigm in order establish differences in retirement planning between professional soccer players from two countries (South Africa and Poland) though statistical procedures.

\subsection{Sample}

In South Africa two hundred and fifty professional soccer players who played for clubs in the Premier Soccer League (PSL) were approached to complete a questionnaire on retirement planning. The PSL, which attracts huge sponsorship, spectatorship and participation, is the highest soccer league in South Africa. Through this process one hundred and ninety three $(n=193)$ fully completed questionnaires were received.

Regarding the Polish sample, three hundred professional soccer players in the Ekstraklasa - the top Polish professional league as well as $1^{\text {st }}$ league were identified and approached to complete the same questionnaire used for the South African sample. Finally, two hundred and fifty six $(n=256)$ fully completed questionnaires were used as the base for further analysis.

\subsection{Instrument and procedures}

The retirement planning questionnaire (RPQ) (Maseko \& Surujlal, 2012) which was developed for the South African sample was used in the study. In South Africa the questionnaire was administered to the participants during their training sessions at their club's training fields.

The back-translation method was used to translate the questionnaire into Polish. The questionnaire was then administered to the Polish sample in their clubs, during their training session as well. Back-translation is a 3-step translation method which requires re-translating a completed translation back into the source language and comparing that new translation with the original text to ascertain whether there are inconsistencies between the two (Tyupa, 2011) and reconciling any meaningful differences between the two.

\subsection{Statistical Analyses}

Descriptive statistics were used to report on the demographic profile of the samples. Factor analysis was conducted to identify factors influencing the retirement planning of the participants in both countries. T-tests were conducted to ascertain whether there were differences in retirement planning between Polish and South African professional soccer players.

\section{Results}

\subsection{Demographics}

The majority of the participants in both samples, as indicated in Table 1, have been playing professional soccer for between 2 and 5 years. While the duration of the contracts for the South African sample was at the maximum of 4 years, twenty $(n=20)$ of the Polish participants had up to 6-year contacts. 
Table 1. Profile of respondents

\begin{tabular}{|c|c|c|c|c|c|}
\hline \multirow[b]{2}{*}{ Variable } & \multirow[b]{2}{*}{ Categories } & \multicolumn{2}{|c|}{$\begin{array}{c}\text { South African } \\
\text { sample }\end{array}$} & \multicolumn{2}{|c|}{ Polish sample } \\
\hline & & $\mathbf{n}$ & $\%$ & $\mathbf{n}$ & $\%$ \\
\hline \multirow{4}{*}{$\begin{array}{l}\text { A1. How long playing professional } \\
\text { soccer }\end{array}$} & $<2$ years & 56 & 29 & 48 & 18.8 \\
\hline & 2 - 5 years & 77 & 39.9 & 94 & 36.7 \\
\hline & $6-9$ years & 55 & 28.5 & 66 & 25.8 \\
\hline & $>9$ years & 5 & 2.6 & 48 & 25.8 \\
\hline \multirow[t]{6}{*}{ A2. Length of contract in current club } & 1 year & 15 & 7.8 & 81 & 31.6 \\
\hline & 2 years & 37 & 19.2 & 64 & 25.0 \\
\hline & 3 years & 136 & 70.5 & 50 & 19.5 \\
\hline & 4 years & 5 & 2.6 & 26 & 10.2 \\
\hline & 5 years & - & - & 20 & 7.8 \\
\hline & 6 years and more & - & - & 15 & 5.9 \\
\hline \multirow{5}{*}{$\begin{array}{l}\text { A3. Number of clubs played } \\
\text { professionally including current club }\end{array}$} & 1 & 58 & 30.1 & 69 & 27.0 \\
\hline & 2 & 79 & 40.9 & 98 & 38.3 \\
\hline & 3 & 40 & 20.7 & 51 & 19.9 \\
\hline & 4 & 15 & 7.8 & 25 & 9.8 \\
\hline & 5 and more & 1 & 0.5 & 13 & 5.1 \\
\hline \multirow[t]{5}{*}{ A4. Highest academic qualification } & Matric & 125 & 64.8 & 19 & 7.4 \\
\hline & Certificate & 49 & 25.4 & 51 & 19.9 \\
\hline & Diploma & 14 & 7.3 & 69 & 27.0 \\
\hline & Degree & 3 & 1.6 & 54 & 21.1 \\
\hline & Other & 2 & 1 & 63 & 24.6 \\
\hline \multirow[t]{5}{*}{ A5. Age group } & 16-20 years & 28 & 14.5 & 51 & 19.9 \\
\hline & 21-25 years & 95 & 49.2 & 69 & 27.0 \\
\hline & 26-30 years & 56 & 29 & 73 & 28.5 \\
\hline & $31-35$ years & 14 & 7.3 & 41 & 16 \\
\hline & Over 35 years & 0 & 0 & 22 & 8.6 \\
\hline \multirow{2}{*}{$\begin{array}{l}\text { A6. Current club is away from home } \\
\text { town }\end{array}$} & Away from home & 122 & 63.2 & 144 & 44.5 \\
\hline & $\begin{array}{l}\text { Play in my } \\
\text { hometown }\end{array}$ & 71 & 36.8 & 142 & 55.5 \\
\hline \multirow[t]{3}{*}{ A7. Marital status } & Single & 166 & 80.6 & 138 & 53.9 \\
\hline & Married & 27 & 14 & 97 & 37.9 \\
\hline & Divorced & 0 & 0 & 21 & 8.2 \\
\hline \multirow[t]{2}{*}{ A8. Do you have savings account? } & Yes & 183 & 94.8 & 162 & 63.3 \\
\hline & No & 10 & 5.2 & 94 & 36.7 \\
\hline \multirow{2}{*}{$\begin{array}{l}\text { A9. Do you have a retirement } \\
\text { insurance policy? }\end{array}$} & Yes & 50 & 25.9 & 153 & 59.8 \\
\hline & No & 143 & 74.1 & 103 & 40.2 \\
\hline \multirow[t]{2}{*}{ A10. Do you have any investments? } & Yes & 86 & 44.6 & 63 & 24.6 \\
\hline & No & 107 & 55.4 & 193 & 75.4 \\
\hline \multirow{2}{*}{$\begin{array}{l}\text { A11. Did you receive any financial } \\
\text { literacy training? }\end{array}$} & Yes & 66 & 34.2 & 149 & 58.2 \\
\hline & No & 127 & 65.8 & 107 & 41.8 \\
\hline \multirow{2}{*}{$\begin{array}{l}\text { A12. Are you aware what your } \\
\text { financial worth will be upon } \\
\text { retirement? }\end{array}$} & Yes & 41 & 21.2 & 98 & 38.3 \\
\hline & No & 152 & 78.8 & 158 & 61.7 \\
\hline \multirow{2}{*}{$\begin{array}{l}\text { A13. Do you have an idea of what } \\
\text { career you will pursue after retirement } \\
\text { from playing soccer? }\end{array}$} & Yes & 55 & 28.5 & 151 & 59.0 \\
\hline & No & 138 & 71.5 & 105 & 41.0 \\
\hline
\end{tabular}

Aproximately $25 \%(\mathrm{n}=22)$ of the Polish participants continued playing professional soccer beyond the age of 30 years while the majority $(n=179)$ of the South African participants played professional soccer up to the age of 30 years. Differences were observed in both samples regarding the number of clubs played for. Polish players played for more clubs than their South African counterparts. There was a huge difference between the two samples regarding the qualifications of the participants. There were variations in the 
qualifications of the players. More Polish participants $(n=123)$ had a tertiary qualification compared to their South African participants $(n=17)$. A greater number South African participants $(n=183)$ than Polish participants $(n=162)$ had a savings account despite the fact that more South African participants $(n=66)$ than Polish participants $(n=149)$ did not receive any financial literacy training. Approximately 60 percent of the Polish participants compared to approximately 26 percent of the South African sample had retirement insurance. A higher percentage of the Polish sample (75.4\%) than the South African sample $(55.4 \%)$ had investments.

Participants from the Polish sample appeared to be more prepared for retirement than South African players. In particular differences were noted in financial literacy and career planning. A larger number of Polish participants $(n=55)$ than South African participants $(n=151)$ had an idea of their career path after retirement.

\subsection{Factor analysis}

Four factors, namely preparedness for retirement, financial planning, organisational support and expectations during retirement, associated with retirement planning were identified through factor analysis. The Cronbach alpha reliability for the factors were then calculated. Acceptable reliabilities of over 0.7 for both samples were realised (Nunnally \& Bernstein, 1994).

Table 2. Reliabilities - South African and Polish samples

\begin{tabular}{lll}
\hline & South African sample & Polish sample \\
\hline Factor & Cronbach alpha & Cronbach alpha \\
\hline Preparedness for retirement & .971 & .855 \\
\hline Financial planning & .955 & .845 \\
\hline Organisational support & .939 & .826 \\
\hline Expectations during retirement & .921 & .765 \\
\hline
\end{tabular}

\section{Independent sample $T$ test}

In order to examine whether significant differences exists between the Polish and South African sample with regard to preparedness for retirement, financial planning, organisational support and expectations during retirement, an independent sample t-test was conducted. These results are reported in Table 3.

Independent samples t-test is used when means scores are compared for two different groups of participants (Pallant, 2010). Significant differences in scores for the South African and Polish samples (SA sample: $\mathrm{M}=2.70 ; \mathrm{SD}=0.86$; Polish sample: $\mathrm{M}=3.45 ; \mathrm{SD}=0.70 ; \mathrm{t}=-$ $9.831 ; \mathrm{p}<0.05)$ were found for the preparedness for retirement factor. In terms of practical significance, Cohen's (1988:284) proposed guidelines were used for interpreting the value $(0.01=$ small effect; $0.06=$ moderate effect; $0.14=$ large effect $)$. The effect size $=0.86$ thus indicating a large practical significance. On examining the means it seems that Polish players are more prepared for retirement compared to their South African counterparts.

On examining the financial preparedness for retirement of the South African and Polish samples, significant differences in scores for the South African and Polish samples (SA sample: $\mathrm{M}=2.49 ; \mathrm{SD}=0.87$; Polish sample $\mathrm{M}=2.67 ; \mathrm{SD}=0.93 ; \mathrm{t}=-2.128 ; \mathrm{p}<0.05$ ) were observed. In terms of practical significance, the effect size $=0.20$ thus indicating a large practical significance. An examination of the means reveals that Polish players are slightly more financially prepared for retirement compared to their South African counterparts. This 
may be ascribed to South African players' lower levels of education. Nguyen and Rozsa (2019), in support of this assertion, argued that financial capability depended on the level of one's education.

In terms of getting organisational support for retirement planning, significant differences were also noted in scores for the South African and Polish samples (SA sample: $\mathrm{M}=2.36 ; \mathrm{SD}=0.87$; Polish sample $\mathrm{M}=2.66 ; \mathrm{SD}=0.89 ; \mathrm{t}=-3.626 ; \mathrm{p}<0.05$ ). With regard to practical significance, the effect size $=0.34$ thus indicating a large practical significance. A comparison of the means revealed that Polish players obtain more organisational support for retirement compared to their South African counterparts.

Finally, regarding expectations during retirement, significant differences were also noted in scores for the South African and Polish samples (SA sample: $M=2.22 ; S D=0.84$; Polish sample $\mathrm{M}=3.61 ; \mathrm{SD}=1.03 ; \mathrm{t}=-15.723 ; \mathrm{p}<0.05)$. In terms of practical significance, the effect size $=1.35$ thus indicating a large practical significance. A comparison of the means indicate that Polish players' expectations during retirement are much higher than their South African counterparts.

Table 3. Independent sample-t tests

\begin{tabular}{|c|c|c|c|c|c|c|c|c|c|c|}
\hline & & \multicolumn{2}{|c|}{$\begin{array}{c}\text { Levene's Test } \\
\text { for Equality of } \\
\text { Variances }\end{array}$} & \multicolumn{7}{|c|}{ t-test for Equality of Means } \\
\hline & & \multirow[t]{2}{*}{$\mathrm{F}$} & \multirow[t]{2}{*}{ Sig. } & \multirow[t]{2}{*}{$\mathrm{t}$} & \multirow[t]{2}{*}{ df } & \multirow[t]{2}{*}{$\begin{array}{l}\text { Sig. (2- } \\
\text { tailed) }\end{array}$} & \multirow[t]{2}{*}{$\begin{array}{c}\text { Mean } \\
\text { Differenc } \\
\mathrm{e}\end{array}$} & \multirow[t]{2}{*}{$\begin{array}{c}\text { Std. Error } \\
\text { Differenc } \\
\text { e }\end{array}$} & \multicolumn{2}{|c|}{$\begin{array}{l}\text { 95\% Confidence } \\
\text { Interval of the } \\
\text { Difference }\end{array}$} \\
\hline & & & & & & & & & Lower & Upper \\
\hline \multirow[t]{2}{*}{$\begin{array}{l}\text { Polish_Preparedn } \\
\text { ess for retirement }\end{array}$} & $\begin{array}{c}\text { Equal } \\
\text { variances } \\
\text { assumed }\end{array}$ & 10.522 & 0.001 & -10.126 & 447 & 0.000 & -0.74988 & 0.07406 & -0.89543 & -0.60433 \\
\hline & $\begin{array}{c}\text { Equal } \\
\text { variances } \\
\text { not } \\
\text { assumed }\end{array}$ & & & -9.831 & 361.627 & $0.000 *$ & -0.74988 & 0.07628 & -0.89988 & -0.59988 \\
\hline \multirow[t]{2}{*}{$\begin{array}{l}\text { Polish_Financial } \\
\text { planning }\end{array}$} & $\begin{array}{c}\text { Equal } \\
\text { variances } \\
\text { assumed }\end{array}$ & 4.618 & 0.032 & -2.107 & 447 & 0.036 & -0.18282 & 0.08676 & -0.35332 & -0.01233 \\
\hline & $\begin{array}{c}\text { Equal } \\
\text { variances } \\
\text { not } \\
\text { assumed }\end{array}$ & & & -2.128 & 426.996 & $0.034 *$ & -0.18282 & 0.08593 & -0.35173 & -0.01392 \\
\hline \multirow[t]{2}{*}{$\begin{array}{l}\text { Polish_Organisati } \\
\text { onal support }\end{array}$} & $\begin{array}{c}\text { Equal } \\
\text { variances } \\
\text { assumed }\end{array}$ & 0.018 & 0.894 & -3.626 & 447 & 0.000 & -0.30591 & 0.08437 & -0.47173 & -0.14009 \\
\hline & $\begin{array}{c}\text { Equal } \\
\text { variances } \\
\text { not } \\
\text { assumed }\end{array}$ & & & -3.633 & 416.784 & $0.000 *$ & -0.30591 & 0.08420 & -0.47142 & -0.14041 \\
\hline \multirow[t]{2}{*}{$\begin{array}{l}\text { Polish_Expectatio } \\
\text { ns during } \\
\text { retirement }\end{array}$} & $\begin{array}{c}\text { Equal } \\
\text { variances } \\
\text { assumed }\end{array}$ & 19.556 & 0.000 & -15.283 & 447 & 0.000 & -1.39375 & 0.09119 & -1.57297 & -1.21453 \\
\hline & $\begin{array}{c}\text { Equal } \\
\text { variances } \\
\text { not } \\
\text { assumed }\end{array}$ & & & -15.723 & 444.237 & $0.000 *$ & -1.39375 & 0.08865 & -1.56797 & -1.21953 \\
\hline
\end{tabular}

*Significant at $p<0.05$

Table 4 provides an illustration of group means and effect sizes associated with the SA and Polish samples. 
Table 4. Group means and effect sizes

\begin{tabular}{llcccc}
\hline \multicolumn{6}{c}{ Group Statistics } \\
\hline \multicolumn{2}{c}{ Group } & $\mathrm{N}$ & Mean & Std. Deviation & \multirow{2}{*}{ Effect size } \\
\hline \multirow{2}{*}{$\begin{array}{l}\text { Polish_Preparedness } \\
\text { for retirement }\end{array}$} & RSA & 193 & 2.7021 & 0.86741 & \multirow{2}{*}{0.86} \\
\cline { 2 - 5 } $\begin{array}{l}\text { Polish_Financial } \\
\text { planning }\end{array}$ & Poland & 256 & 3.4520 & 0.70103 & \\
\cline { 2 - 5 } $\begin{array}{l}\text { Polish_Organisational } \\
\text { support }\end{array}$ & RSA & 193 & 2.4952 & 0.87458 & \multirow{2}{*}{0.20} \\
\cline { 2 - 5 } $\begin{array}{l}\text { Polish_Expectations } \\
\text { during retirement }\end{array}$ & RSA & 256 & 2.6780 & 0.93590 & \multirow{2}{*}{0.34} \\
\cline { 2 - 5 } & Poland & 193 & 2.3601 & 0.87752 & \multirow{2}{*}{1.35} \\
\hline
\end{tabular}

\section{Discussion}

\subsection{Demographics}

It is interesting to note that the duration of the contacts of the South African participants is not more than 4 years while some of the Polish participants' contracts extend to 6 years. Surujlal, Singh and Hollander (2004) in their study on the job security of sport coaches argued that the nature and duration of a contact impacts on the level of job security one experiences. One would therefore expect that SA professional soccer players would seriously consider their future outside playing professional soccer because of the short duration of their playing contracts. However, this does not appear to be the case resulting in them being ill-prepared for retirement.

Majority of South African participants played professional soccer up to the age of 30 years indicating that they retire earlier from professional soccer when compared to their Polish counterparts and some who play professional soccer beyond the age of 35 years. Rosenkoetter and Garris (2001) argue that although early retirement is increasingly becoming a newer phenomenon, retirement itself is no longer an unexpected occurrence. It is therefore surprising that retirement is not taken seriously by professional soccer players.

The large difference in the number of participants having a tertiary qualification between the two samples suggests that the Polish participants may have more avenues and greater scope for a career outside playing professional soccer after retirement. Furthermore, the high percentage of Polish participants $(60 \%)$ suggests that they may be more prepared for retirement than their South African counterparts. Torregrosa, Boixado's, Valiente and Cruz (2004) argue that if athletes experience retirement as a process, the transition to mainstream society may be smoother. As part of the retirement process soccer clubs should ensure that their players develop themselves through further education thereby increasing their options of other forms of employment after their professional playing days.

Another point which suggests that the Polish participants may be more prepared for retirement is that more Polish participants had investments than South African participants. The fact that a higher percentage of Polish participants had financial training explains why more Polish participants were aware of their financial worth once they retired from playing professional soccer. It also explains why Polish participants have more investments. A plausible explanation for a low number of Polish participants having a savings account was because their income was channelled towards investments. This implies that Polish participants focussed more on long term financial security than their SA counterparts. Elder and Rudolph (1999) are of the view that the decisions one makes about savings/investments 
early in one's working life determine the resources that will be available during the retirement years.

\subsection{Independent T-tests, group means and effect sizes}

It is evident from the results from the t-tests and examination of the means that Polish players were more prepared for retirement $($ mean $=3.45)$ than SA players $($ mean=2.70). A plausible reason for this may be that Polish players had a longer career span than SA players. In a cross country comparison of French and Swedish athletes, Stambulova et al. (2007) found that French athletes who retired earlier than Swedish athletes were less prepared for retirement and experienced greater difficulty to cope with their retirement. Alfermann et al. (2004) also posited that athletes who planned for their retirement were more prepared for retirement and could use their resources more meaningfully.

The results also indicate that Polish players (mean= 2.67) planned slightly more efficiently financially for their retirement than SA players (mean= 2.49). Many professional athletes experience financial difficulties because of poor financial planning, received more organisational support from their clubs and had greater expectations of their retirement. This implies that both Polish clubs as well as players focus and attend to their retirement planning to a greater extent than those in South Africa. A plausible reason for this difference may be attributed to the fact that South African professional players may be less financially prepared for retirement (Maseko \& Surujlal, 2011) or players being prematurely recruited from the schooling system and being unable to complete their studies due to the high demands of playing soccer. While success in sport requires a high level of dedication, training and time it should not be at the expense of planning for and securing a comfortable retirement (Anon, 2019).

\section{Conclusion}

The purpose of the study was to ascertain whether there were differences in retirement planning between Polish and South African professional players. Indeed, differences were noted. These differences may be attributed to a number of factors such as the professional players approach to their careers, organisational support as well as the management of professional soccer clubs. The results of the study underlie the fact that retirement planning cannot be understated and that soccer clubs in general need to do much more to assist their players to prepare for a more stable life once their professional playing days are over.

It is evident from the results that because of the Polish soccer players' increased financial literacy they have more investments and are more aware of what career path they would follow after retirement. A plausible reason for this difference could be attributed to the career planning of soccer players in both countries as well as the organisational support provided by the soccer clubs. It is recommended that professional soccer clubs in South Africa adopt salient strategies of professional Polish soccer clubs to support their players in being better prepared for retirement.

It is therefore recommended that South African soccer players attend short courses or workshops on financial literacy to increase their preparedness for retirement.

Anecdotal evidence suggests that players who have good managers are able to benefit from their expertise and experience to plan for their future. Therefore it is imperative that professional players choose their managers wisely. Managers are part of the support that an organisation provides to its players. The type of management support they receive from their organisations will enable them to plan their futures accordingly. 
The results also indicate that the career-span of South African players is far shorter than that of their Polish counterparts. Probable reasons for this need to be investigated in future studies. Also future studies necessitates the inclusion of more countries to establish whether there is a trend in the retirement planning of professional soccer players.

It is important for soccer clubs to arrange pre-retirement workshops/courses for their players so that they develop a positive attitude towards retirement, become aware of the options available to them once their professional playing days come to an end, and they are enabled to plan for their retirement. Such workshops/courses can also psychologically prepare them for retirement as may athletes who are forced into premature retirement may experience vulnerability which has to be coped with.

\section{References}

Alfermann, D., (2000). Causes and consequences of sport career termination. In: D. Lavallee and P. Wylleman, eds. Career transitions in Sport: International Perspectives (pp. 4558). Morgantown, WV: Fitness Information Technology.

Alfermann, D., Stambulova, N., \& Zemaityte, A. (2004). Reactions to sport career termination: A cross-cultural comparison of German, Lithuanian, and Russian athletes. Psychology of Sport and Exercise, 5, 61-75.

Anon (2019). Life after the game: Athletes share their retirement planning tips. Retrieved from: https://www.rbcwealthmanagement.com/gg/en/research-insights/life-after-thegame-athletes-share-their-retirement-planning-tips/detail/. 25/06/2019.

Bilan, Y., Mishchuk, H., Samoliuk, N., \& Yurchyk, H. (2020). Impact of Income Distribution on Social and Economic Well-Being of the State. Sustainability, 12(1), 429; doi:10.3390/su12010429

Cohen, J. (1988). Statistical Power Analysis for the Behavioral Sciences (2nd ed.). Hillsdale, NJ: Lawrence Earlbaum Associates.

Drawer, S, \& Fuller, C.W. Perceptions of retired professional soccer players about the provision of support services before and after retirement. British Journal of Sports Medicine, 36(1), 33-8.

D'Silva, J. L., \& Samah, A. A. (2018). Holistic well-being of Japanese retirees in Malaysia. Journal of International Studies Vol, 11(3), 95-103.

Elder, H.W., \& Rudolph, P.M. (1999). Does retirement planning affect the level of retirement satisfaction? Financial Services Review, 8, 117-127.

Fortunato, V., \& Marchant, D. (1999). Forced retirement from elite football In Australia. Journal of Loss and Trauma, 4(3), 269-280.

Gerson, J., \& Landau, S.P. (2017). What does retirement planning for professional athletes entail? Retrieved from https://www.worth.com/advice/what-does-retirement-planningfor-professional-athletes-entail/. 25/06/2019.

Gouttebarge, V., \& Aoki, H. (2014). Lifespan perspective of professional footballers' health. Asian Journal of Sports Medicine, 5(4), e23813.

Hinton, P., Johnstone, B., Blaine, E., \& Bodling, A. (2011). Effects of Current Exercise and Diet on Late-Life Cognitive Health of Former College Football Players. The Physician and Sports medicine, 39(3), 11-22.

Lavallee, D. (2005). The effect of a life development intervention on sports career transition adjustment. The Sport Psychologist, 19, 193-202.

Locher, J. M. (2016). Factors Impacting the Retirement Experience of Professional Football Players. Masters Thesis. Graduate School of Vanderbilt University. Available at: https://etd.library.vanderbilt.edu/available/etd-03232016-112909/.../Locher.pdf 
Maseko, J., \& Surujlal, J. (2011). Retirement planning among South African professional soccer players: A qualitative study of players' perceptions. African Journal for Physical, Health Education, Recreation and Dance (AJPHERD), Special Edition, September (Supplement), 157-171.

McKenna, J., \& Thomas, H. (2007). Enduring injustice: a case study of retirement from professional rugby union. Sport, Education and Society, 12 (1), 19-35.

Mendryk, I. (2017). Retirement Age: Preferences of Employees Representing Various Age Groups. Economics and Sociology, 10(4), 29-40. doi:10.14254/2071-789X.2017/10-4/3

Mertl, J., Mihola, J., \& Valenčík, R. (2019). Incentive extension of pay-as-you-go pension system. Journal of International Studies, 12(4), 195-213. doi:10.14254/20718330.2019/12-4/13

Mishchuk, H., \& Grishnova, O. (2015). Empirical study of the comfort of living and working environment-Ukraine and Europe: comparative assessment. Journal of International Studies, 8 (1), 67 - 80. doi: 10.14254/2071-8330.2015/8-1/6

Mishchuk, H., Samoliuk, N., \& Bilan, Y. (2019). Measuring social justice in the light of effectiveness of public distributive policy. Administration \& Public Management Review, (32). 63-76. DOI: 10.24818/amp/2019.32-05.

Nguyen, T. A. N., \& Rozsa, Z. (2019). Financial Literacy and Financial Advice Seeking for Retirement Investment Choice. Journal of Competitiveness, 11(1), 70-83.

Nunnally, J. C., \& Bernstein, I. H. (1994). Psychometric theory (3rd ed.). New York, NY: McGraw-Hill, Inc.

Pallant, J. (2010). SPSS survival manual: A step by step guide to data analysis using SPSS. Maidenhead :Open University Press/McGraw-Hill.

Riffkin, R. (2014). Average U.S. Retirement Age Rises to 62. Available at http://www.gallup.com/poll/168707/average-retirement-age-rises.aspx

Rosenkoetter, M.M., \& Garris, J.M. (2001). Retirement planning, use of time and psychosocial adjustment. Issues in Mental Health Nursing, 22, 703-722.

Stambulova, S., \& Japhag. (2007). Athletic Retirement: A Cross-National Comparison of Elite French and Swedish Athletes. Psychology of Sport and Exercise, 8, 101-18.

Surujlal, J. (2016). Influence of Organizational Support on Retirement Planning and Financial Management of Professional Soccer Players. Polish Journal of Management Studies, 13(2), 164-174.

Surujlal, J., \& Maseko, J. (2012). Retirement planning among South African professional soccer players. African Journal for Physical, Health Education, Recreation and Dance (AJPHERD), December (Supplement 2), 30-44.

Surujlal, J., Singh, P. C., \& Hollander, W.J. (2004). A comprehensive analysis of the job security of professional sports coaches in South Africa. South African Journal for Research in Sport, Physical Education and Recreation, 26(2), 105-116.

Torregrosa, M, Boixado's, M., Valiente, L. \& Cruz, J. (2004). Elite athletes' image of retirement: the way to relocation in sport. Psychology of Sport and Exercise, 5, 35-43.

Tyupa, S. (2011). A theoretical framework for back-translation as a quality assessment tool. New Voices in Translation Studies, 7, 35-46. 